JURNAL KETAHANAN NASIONAL

Vol. 24, No.2, Agustus 2018, Hal 239-260

DOI:http://dx.doi.org/ 10.22146/jkn.30999

ISSN:0853-9340(Print), ISSN:2527-9688(Online)

Online sejak 28 Desember 2015 di :http://jurnal.ugm.ac.id/JKN

VOLUME 24

No. 2, Agustus 2018

Halaman 239-260

\title{
Meningkatkan Keamanan Energi Melalui Perincian Indikator Energi Terbarukan dan Efisiensi Guna Membangun Ketahanan Nasional Dari Daerah
}

\author{
Erkata Yandri \\ Sekolah PascasarjanaEnergi Terbarukan, Universitas Darma Persada \\ Pusat Studi Energi Terbarukan, Universitas Darma Persada \\ email: erkata@gmail.com,erkata@pasca.unsada.ac.id \\ Ratna Ariati \\ Sekolah Pascasarjana Energi Terbarukan, Universitas Darma Persada \\ Pusat Studi Energi Terbarukan, Universitas Darma Persada \\ email: ratna.ariati@gmail.com \\ Riki Firmandha Ibrahim \\ Sekolah Pascasarjana Energi Terbarukan, Universitas Darma Persada \\ email: r.firmandha@gmail.com
}

\begin{abstract}
The purpose of this paper was to discussed how to developed the concept of Indonesia 's energy security model with of Renewable Energy (RE) and Energy Efficiency (EE) programs.

To did this, there were four important concepts must be completed: reconceptualized the Indonesia's energy security model; explained the energy security (ES) relationship with the details of the indicator; explained the potential of ET and EE in each sector; explained the role of local government in exploiting the potential of ET and EE.

As an archipelago country divided into several regions, in order to get accurate prediction, our result showed that development Indonesian energy security models needed to be developed properly with more detailed indicators of RE and EE. To pursued the goal of national energy policy, the potential of RE and EE in each province should be utilized immediately, the role of local government was very important. The concept of detailed RE and EE indicators would create a contribution for local governments in realizing national energy security.
\end{abstract}

Keywords: Energy Security, Local Government, Renewable Energy, Energy Efficiency, Detailed Indicators

\begin{abstract}
ABSTRAK
Tujuan dari penulisan ini adalah untuk membahas bagaimana mengembangkan konsep model keamanan energi Indonesia dengan program Energi Terbarukan (ET) dan Efisiensi Energi (EE).

Untuk melakukan ini, ada empat konsep penting yang harus diselesaikan: mengkonsepkan kembali model keamanan energi Indonesia; menjelaskan hubungan kemananan energi (ES) dengan perincian indikator; menjelaskan potensi ET dan EE di masing-masing sektor; menjelaskan peran pemerintah daerah dalam memanfaatkan potensi ET dan EE.

Sebagai negara kepulauan yang terbagi menjadi beberapa provinsi, analisis menunjukkan bahwa model keamanan energi Indonesia perlu dikembangkan dengan indikator ET dan EE yang lebih rinci. Untuk mengejar tujuan kebijakan energi nasional, potensi ET dan EE di setiap provinsi harus segera dimanfaatkan, maka peran
\end{abstract}


pemerintah daerah sangat penting. Konsep model indikator ET dan EE yang terperinci ini akan merupakan kontribusi bagi pemerintah daerah dalam mewujudkan keamanan energi nasional.

Kata Kunci: Keamanan Energi, Pemerintah Daerah, Energi Terbarukan, Efisiensi Energi, Indikator Rinci

\section{PENGANTAR}

Energi adalah salah satu kebutuhan masyarakat yang tidak bisa lepas dari kehidupan sehari-hari, tidak hanya secara pribadi tapi juga dalam kehidupan berbangsa dan bernegara. Gangguan pasokan energi secara langsung akan mempengaruhi pertumbuhan ekonomi dan pembangunan suatu negara. Oleh karena itu, masing-masing negara memiliki strategi energi khusus untuk mengamankan pembangunan nasionalnya. Dalam kasus Indonesia, strategi energinya dituangkan dalam bentuk Undang-Undang pada tahun 2007, yaitu Undang-Undang No. 30 Tahun 2007 tentang Energi. Dalam pasal 2 UndangUndang tersebut secara jelas tercantum strategi pengelolaan energi yang pada prinsipnya didasarkan pada asas-asas manfaat, nasionalitas, efisiensi yang setara, nilai tambah ekonomi, keberlanjutan, kesejahteraan masyarakat, pelestarian lingkungan, keamanan nasional, dan integritas. Prinsip-prinsip ini mengarah pada keberlanjutan pembangunan nasional dan keamanan energi atau disebut Energy Security atau disingkat dengan ES.

Yang dimaksud dengan pengelolaan energi sebagaimana tercantum pada pasal 1 Ketentuan Umum dari Undang-Undang tersebut adalah penyelenggaraan kegiatan penyediaan, pengusahaan, dan pemanfaatan energi serta penyediaan cadangan strategis dan konservasi sumber daya energi. Ketentuan tersebut membawa pengertian bahwa pengelolaan energi dilakukan mulai dari hulu hingga hilir seluruh kegiatan yang terkait dengan energi atau dengan kata lain dari mulai penyediaan hingga pemanfaatan akhir oleh pengguna/konsumen energi.Pengelolaan energi di sisi penyediaan meliputi (1). Sumber daya energi tak terbarukan yang akan habis jika dieksploitasi secara terus menerus, antara lain minyak bumi, gas bumi, batubara, gambut, dan serpih bitumen; (2). Sumber daya energi terbarukan (ET) yang berkelanjutan jika dikelola dengan baik, antara lain panas bumi, angin, bioenergi, sinar matahari, aliran dan terjunan air, serta gerakan dan perbedaan suhu lapisan laut; dan (3). Sumber energi baru yang dapat dihasilkan oleh teknologi baik yang berasal dari sumber energi tak terbarukan maupun sumber energi terbarukan, antara lain nuklir, hydrogen, gas metana batu bara (coal bed methane), batu bara tercairkan (liquefied coal), dan batubara tergaskan (gasified coal). Adapun pengelolaan energi di sisi pemanfaatan baik yang menggunakan energi secara langsung maupun tidak langsung dari sumber energi, diamanatkan untuk dilakukan berdasarkan asas-asas pengelolaan yaitu: (1). Mengoptimalkan seluruh potensi sumber daya energi, (2). Mempertimbangkan aspek teknologi, sosial, ekonomi, konservasi, dan lingkungan; (3). Memprioritaskan pemenuhan kebutuhan masyarakat dan peningkatan kegiatan ekonomi di daerah penghasil sumber energi (Undang-Undang No 30, 2007).

Dengan strategi seperti tersebut di muka, diharapkan tujuan pengelolaan energi untuk mendukung pembangunan nasional baik sebagai bahan baku industri maupun sebagai bahan bakar dapat tercapai dan berkelanjutan dalam arti dapat menjamin penyediaan dan pemanfaatan energi untuk generasi sekarang dan yang akan datang. Pada kenyataannya, 
Erkata Yandri, Ratna Ariati, Riki Firmandha Ibrahim -- Meningkatkan Keamanan Energi Melalui Perincian Indikator Energi Terbarukan dan Efisiensi Guna Membangun Ketahanan Nasional Dari Daerah

Gambar 1

Perbandingan Konsumsi Energi Primer Per Jenis Sumber Energi Tahun 2006 Dan 2013

\section{Primary Energy Consumption by Fuel Type in 2006 (MTOE)}

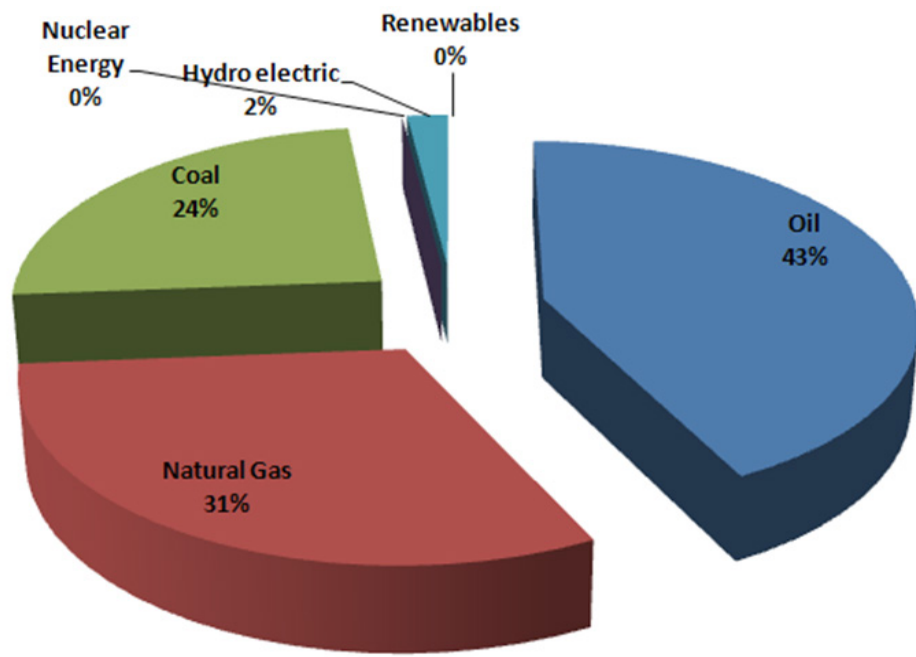

Sumber: Pusdatin ESDM, 2014

\section{Primary Energy Consumption by Fuel in 2013 (MTOE)}

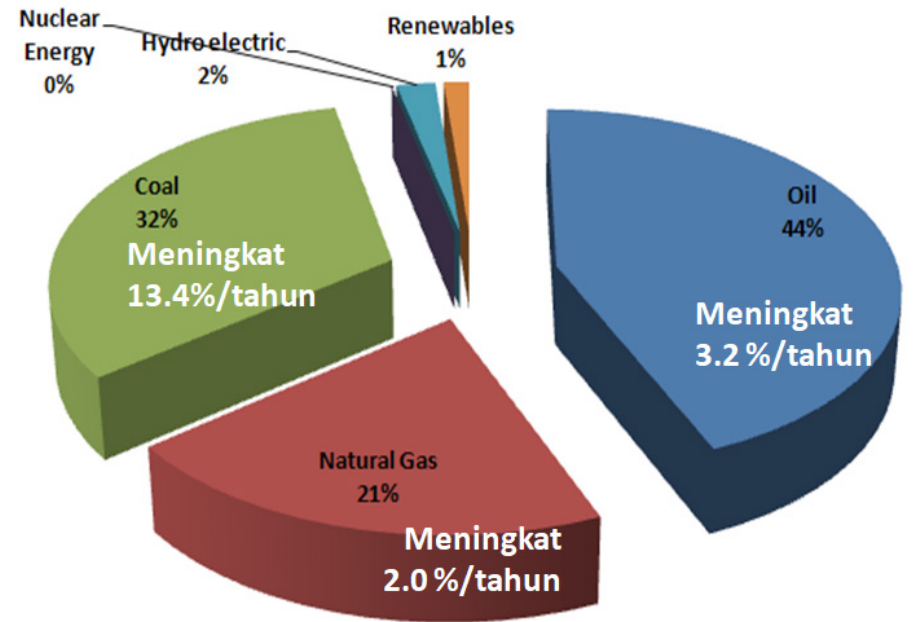

Sumber: Pusdatin ESDM, 2014

sebagaimana pada gambar 1, konsumsi energi Indonesia baik energi primer maupun energi akhir terus meningkat dari tahun ke tahun sejak tahun 2006 sampai dengan 2013 secara berturutan dengan rata-rata 3,2\% (oil), 2,0\% (gas) dan 13,4\% (coal), (Pusdatin ESDM, 2014).
Dalam perkembangannya telah terjadi perubahan paradigma di bidang energi, yang semula dipandang hanya sebagai komoditi yaitu dijual untuk meningkatkan pendapatan yang digunakan untuk pembangunan nasional, kini langsung 
Gambar 2

Konsumsi Energi Akhir Menurut Sektor Tahun 2013

(Tidak Termasuk Biomassa Tradisional)

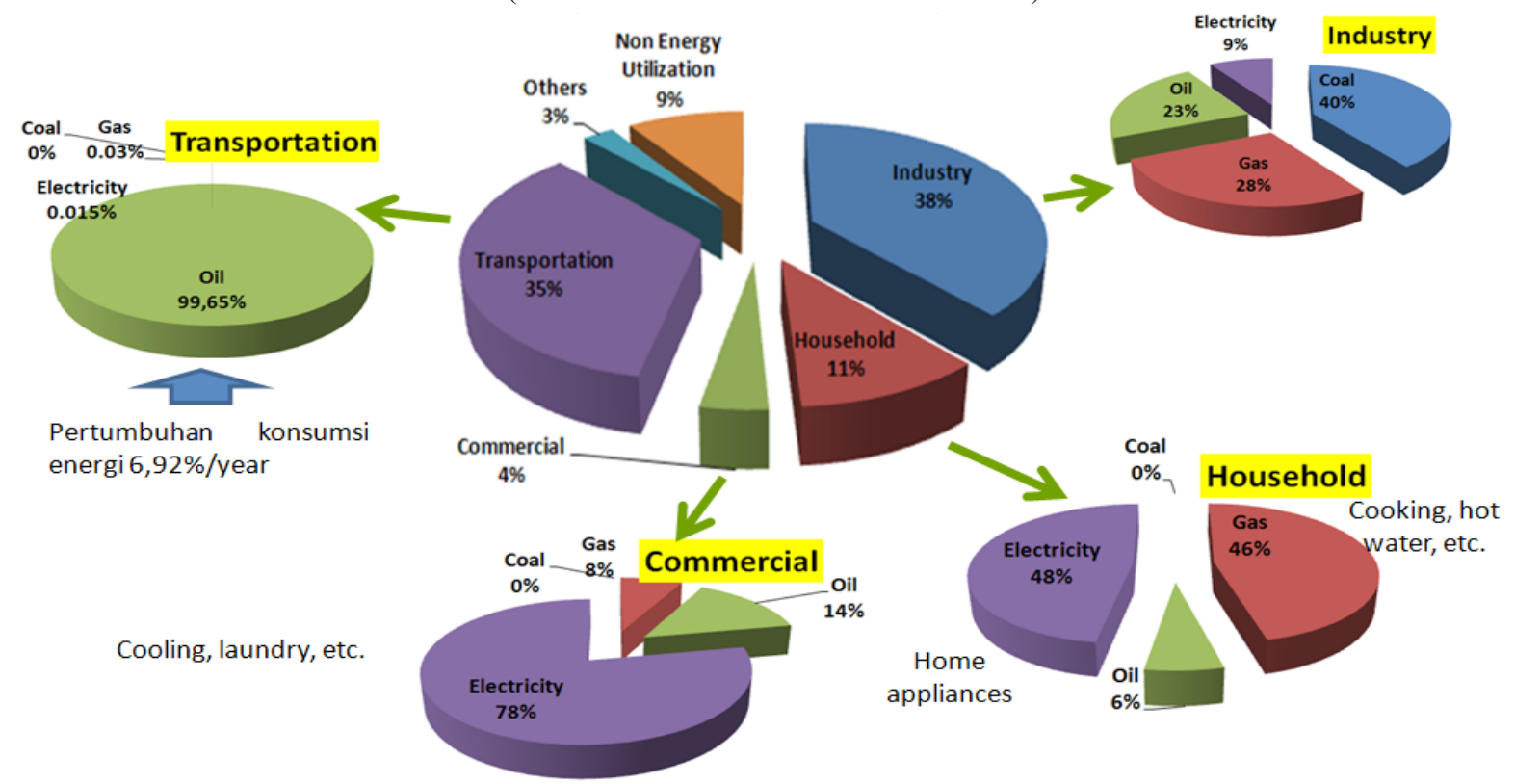

Sumber: British Petroleum (BP), 2017.

dipergunakan sebagai modal pembangunan untuk mencapai kemandirian energi (Harris, 2018). Perubahan paradigma energi tersebut dituangkan dalam Peraturan Pemerintah Nomor 79 Tahun 2014 tentang Kebijakan Energi Nasional. Tujuan dari kebijakan ini adalah untuk mengoptimalisasikan pemanfaatan energi guna (1). Pembangunan ekonomi nasional; (2). Penciptaan nilai tambah di dalam negeri; (3). Penyerapan tenaga kerja; (4). Peningkatan porsi gas dan batubara domestic dibanding ekspor; (5). Peningkatan sumber energi insitu (energi baru terbarukan dan PLTU Mulut Tambang); (6). Peningkatan konektivitas energi.

Dengan kebijakan energi ini dimaksudkan dapat mencapai target kontribusi energi terbarukan (ET) ke dalam bauran energi nasional masing-masing sekitar $23 \%$ dan $31 \%$ pada tahun 2025 dan 2050. Kebijakan ini juga bertujuan untuk menghemat konsumsi energi melalui efisiensi energi (EE) sebanyak
17\% dan 39\% (dengan skenario Business as Usual) pada tahun 2025 dan 2050 (PP No 79 Tahun 2014).

Kebijakan tersebut dianggap sangat ambisius. Diprediksi, konsumsi energi akan terus meningkat tajam seiring dengan pertumbuhan penduduk sekitar 1,49\% per tahun dan pertumbuhan ekonomi sekitar 5-7\% per tahun (Badan Pusat Statistik, 2014; BPPT, 2016), maka diperkirakan pada tahun 2050, kontribusi energi terbarukan hanya bisa mencapai 13,7\% (untuk skenario tinggi), atau $14,9 \%$ (untuk skenario rendah). Karena itu, dibutuhkan upaya besar dari semua pihak di dalam negeri, baik dari sisi penyediaan maupun permintaan untuk mencapai tujuan tersebut.

Kita dapat membandingkan dengan status konsumsi energi per sektor dan per jenis energi final, seperti yang ditunjukkan pada gambar 2 (British Petroleum (BP), 2017). Ini menunjukkan bahwa keamanan energi 
Gambar 3

Tiga Demensi Trilemma Energi

\section{ENERGY EQUITY}

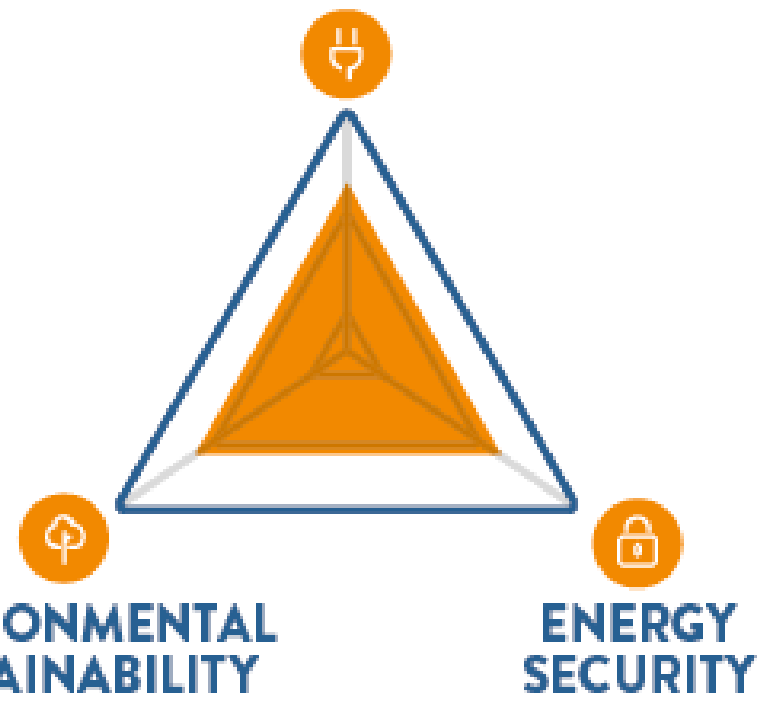

Sumber: World Energy Council, 2017.

Indonesia cukup rentan dan lemah (Mujiyanto and Tiess, 2013),terutama dalam menghadapi trilemmaenergi (Gunningham, 2013).

Keberlajutan energi (energy sustainability) dari suatu negara, sebagaimana ditunjukkan pada gambar 3, didasarkan pada tiga demensi inti, yaitu (1). Energy security (ES) yang merupakan pengelolaan efektif dari pasokan energi primer domestik maupun sumber daya eksternal, infrastruktur energi yang andal, dan kemampuan penyediaan energi untuk memenuhi kebutuhan saat ini maupun di masa yang akan datang; (2). Energy equity yang dapat menyediakan akses energi dengan harga terjangkau bagi semua penduduk di negara tersebut; (3). Environmental sustainability yang mencakup pencapaian penyediaan dan pemanfaatan energi yang efisien, pengembangan pasokan energi dari energi terbarukan dan sumber energi lain yang rendah karbon. Menyeimbangkan ketiga demensi tersebut menimbulkan trilemma energi dan menjadi dasar kesejahteraan serta daya saing suatu negara. Rentannya dan lemahnya keamanan energi Indonesia dapat dilihat dari letaknya berdasarkan indeks trilemma energi yang menduduki peringkat 75 dari 125 negara (World Energy Council, 2017).

Terlepas dari upaya yang telah dilakukan oleh negara sampai dengan saat ini untuk mengatasi trilemma energi tersebut, dapat dikatakan bahwa capaian di bidang pengembangan energi terbarukan masih sangat rendah. Sebagai gambaran 70 kontrak pengembangan energi baru terbarukan yang ditandatangani oleh para pengembang dengan Perusahaan Listrik Negara pada tahun 2017, pada bulan Juli tahun 2018 sebanyak 45 kontrak di antaranya dikuatirkan gagal karena terkendala oleh tiadanya pendanaan, sebagaimana terlihat pada gambar 4 (Harris, 2018).

Adapun pencapaian di bidang konservasi dan efisiensi energi walaupun belum menggembirakan namun sudah menunjukkan 
Gambar 4

Pencapaian Di Bidang Energi Baru Dan Terbarukan

\section{PROGRESS 70 KONTRAK EBT 2017}

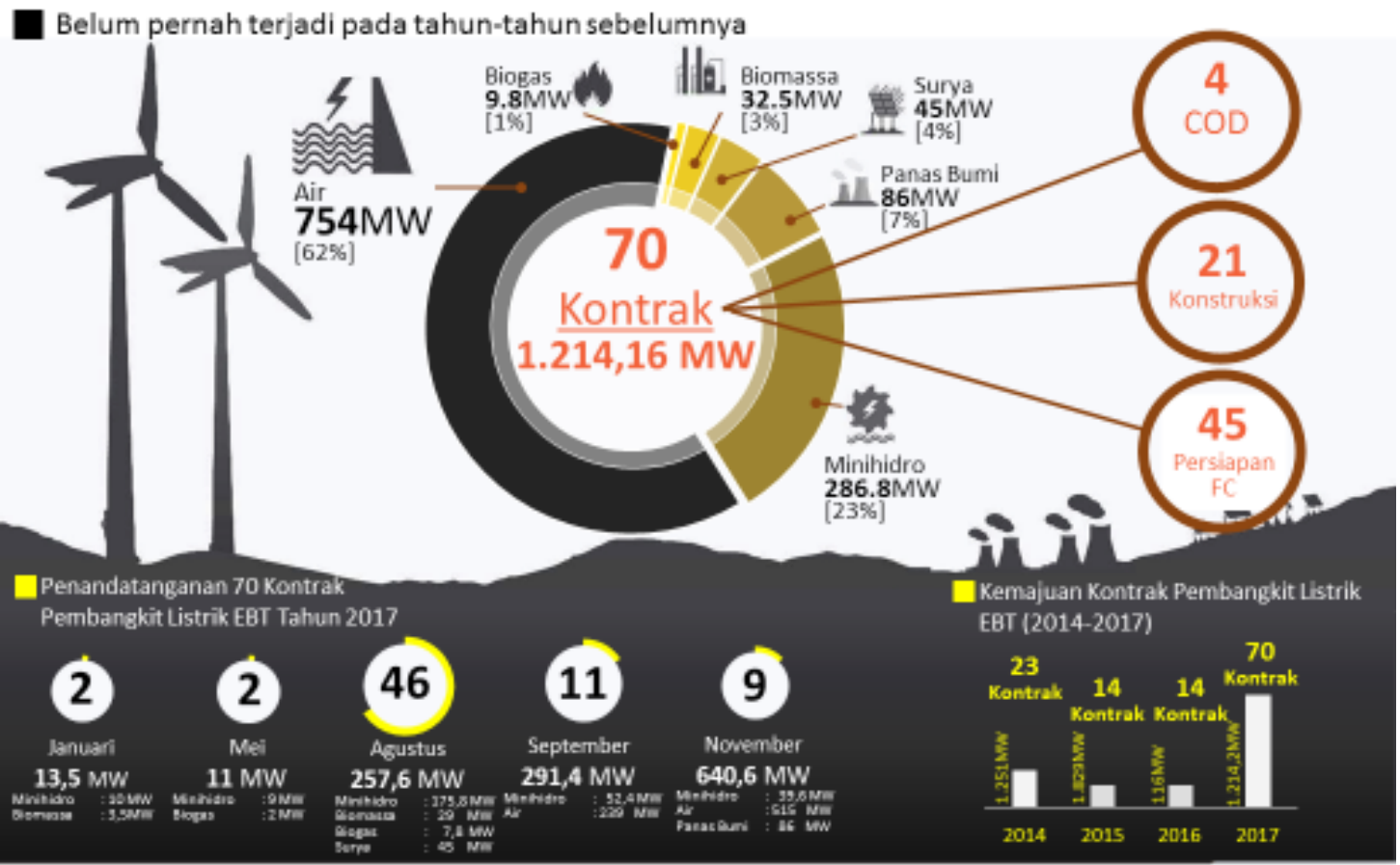

Sumber: Harris, 2018.

kecenderungan yang membaik, sebagaimana dapat dilihat pada gambar 5 (Dirjen EBTKE/ KESDM, 2017).

Peningkatan pemanfaatan energi baru dan energi terbarukan diamanatkan oleh UndangUndang Nomor 30 Tahun 2007 tentang Energi kepada Pemerintah dan Pemerintah Daerah sesuai dengan kewenangannya (UU Energi No. 30 Tahun 2007). Adapun amanat untuk melakukan konservasi energi dibebankan kepada semua pengguna energi pada seluruh tahapan pengelolaan energi. Amanat tersebut tertuang dengan jelas pada pasal 25 ayat 1 bahwa konservasi energi menjadi tanggung jawab semua pihak yaitu pemerintah, pemerintah daerah, pengusaha dan masyarakat.

Penjabaran dari tanggung jawab semua pihak untuk melaksanakan Konservasi Energi tertuang dalam Peraturan Pemerintah Republik Indonesia Nomor 70 Tahun 2009 (Peraturan Pemerintah RI, 2009). Dalam Peraturan tersebut Pemerintah bertanggung jawab terhadap pelaksanaan konservasi energi secara nasional; pemerintah daerah propinsi serta kabupaten/kota bertanggungjawab terhadap pelaksanaan konservasi energi sesuai dengan kewenangannya di daerah masing-masing; pengusaha bertanggung jawab untuk melaksanakan konservasi energi di setiap tahap pelaksanaan usaha dengan menggunakan teknologi yang efisien energi dan/atau menghasilkan produk dan/atau jasa yang hemat energi; adapun masyarakat bertanggung jawab mendukung dan melaksanakan program konservasi energi. Yang dimaksud dengan konservasi energi sebagaimana didefinisikan pada Peraturan 
Gambar 5

Pencapaian Di Bidang Konservasi Dan Efisiensi Energi

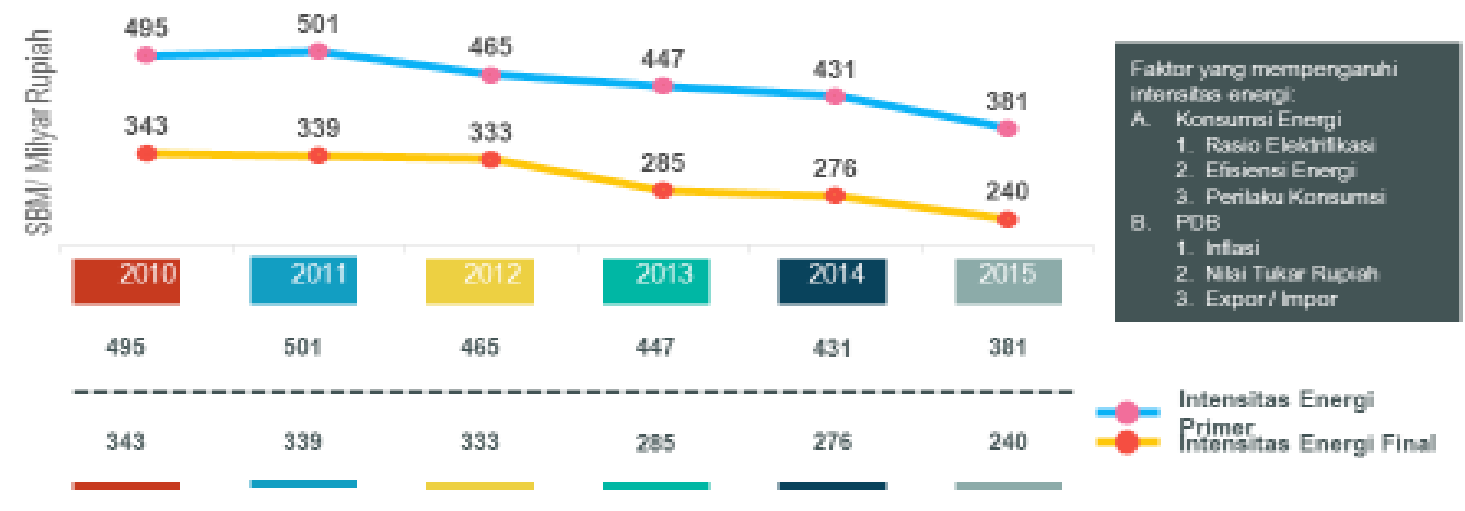

Sumber: Dirjen EBTKE/KESDM, 2017.

Pemerintah Nomor 70 tahun 2009 tersebut adalah upaya sistematis, terencana, dan terpadu guna melestarikan sumber daya energi dalam negeri serta meningkatkan efisiensi pemanfaatannya. Salah satu parameter untuk menilai efisiensi energi nasional adalah intensitas energi yaitu jumlah konsumsi energi per satuan produk domestik bruto (PDB). Semakin rendah intensitas energi, semakin baik efisiensi energinya.Indonesia memiliki intensitas energi yang lebih tinggi di sektor kimia dan petrokimia, sektor industri tekstil dan kulit dibandingkan dengan sektor industri lainnya (Pappas, dkk., 2018).

Pada dasarnya kewenangan Pemerintah di bidang energi antara lain adalah membuat peraturan perundang-undangan, menetapkan kebijakan nasional, menetapkan dan memberlakukan standard dan prosedur. Kewenangan pemerintah propinsi di bidang energi antara lain adalah membuat peraturan daerah propinsi, membina dan mengawasi pengusahaan di lintas kabupaten/kota, serta menetapkan kebijakan pengelolaan di lintas kabupaten/kota. Adapun kewenangan pemerintah kabupaten/kota sama dengan kewenangan pemerintah provinsi namun terbatas di wilayah kabupaten/kota yang bersangkutan (UU Energi No. 30 Tahun 2007).

Selanjutnya, Presiden telah menetapkan Peraturan Presiden nomor 22/2017 tentang Rencana Umum Energi Nasional (RUEN). Rencana ini terdiri dari rencana aksi dari multi sektor untuk mencapai tujuan Kebijakan Energi Nasional (Peraturan Presiden RI, 2017). RUEN perlu dikembangkan lebih lanjut oleh pemerintah daerah sebagai Rencana Umum Energi Daerah (RUED) yang menjadi andalan terhadap keamanan energi nasional.

Keamanan energi merupakan bidang penelitian yang cukup aktif dalam beberapa tahun terakhir, yang dibahas mulai dari konsep definisi, metodologi dan kerangka kerja untuk menentukan dimensi, pemilihan indikator yang ditentukan dengan teknik tertentu (survei, wawancara, d1l), dan pengembangan indeks komposit, serta evaluasi dan penilaian sebagai perbandingan oleh suatu atau sekelompok negara, yang bisa dilihat dari berbagai makalah review (Johansson, 2013; Ang, dkk., 2015; Cherp and Jewell, 2011; Månsson, dkk., 2014; Vivoda, 2010).

Karena ambigu dan memungkinkan beberapa interpretasi, topik keamanan energi 
yang sangat multidisiplin ini disarankan untuk dikategorikan menjadi beberapa perspektif, yaitu: geopolitik, ekonomi, kebijakan, dan teknologi, dengan strategi diversifikasi sangat penting untuk memastikan keamanan energi selama proses pasokan secara keseluruhan (Kiriyama dan Kajikawa, 2014).

Sejauh ini, tidak ada kesepakatan yang jelas dan tegas tentang definisi keamanan energi, namun badan energi internasional (IEA, International Energy Agency) mendefinisikan bahwa keamanan energi sebagai ketersediaan sumber energi tanpa henti dengan harga terjangkau (International Energy Agency (IEA), 2018). Sebelumnya, konsep keamanan energi suatu negara adalah untuk mengamankan akses terhadap sumber energi fosil, seperti minyak (Bielecki, 2002).

Untuk menjawab tantangan keamanan energi yang semakin kompleks, meningkatnya kebutuhan energi dengan semakin menipisnya cadangan minyak dunia, dan meningkatnya tekanan pada perubahan iklim global, yang mencakup isu-isu seperti; volatilitas harga, rantai pasokan, stabilitas politik kawasan penghasil minyak, kelestarian lingkungan, energi terbarukan (ET), efisiensi energi (EE), dan sebagainya, berbagai model telah ditawarkan dengan menerapkan metode dan teknik tertentu yang melibatkan berbagai indikator, disederhanakan menjadi indeks komposit.

Diskusi tentang keamanan energi tidak terlepas dari topik model energi. Model adalah alat yang mudah digunakan untuk melakukan simulasi, karena tidak praktis atau terlalu mahal dilakukan di dunia nyata. Model keamanan energi, seperti model lainnya, merupakan representasi sederhana dari sistem nyata. Model bervariasi, mulai dari yang sederhana hingga yang kompleks, atau dari yang paling penting hingga yang kurang penting, tergantung dari jenis dan jumlah indikator yang digunakan.

Dengan kata lain, kompleksitas masalah keamanan energi saat ini tidak dapat diantisipasi lagi dengan indikator sederhana dan umum, sehingga diperlukan indikator yang kompleks, dengan tetap fokus pada prioritas dan objektifitas. Idealnya, merancang keamanan energi suatu bangsa harus disesuaikan dengan konteks spesifik di suatu negara, seperti; kondisi khusus, tingkat perkembangan ekonomi, persepsi risiko, serta kekuatan sistem energi dan isu geopolitik (Chester, 2010).

Peluang untuk perbaikan keamanan energi masih terbuka lebar karena masih ada celah dan kebebasan untuk indikator tertentu (Ang, dkk., 2015). Intinya, bagaimana Indonesia memperbaiki kemampuan internal pada pasokan energi dengan mengurangi ketergantungan dari negara lain. Sebenarnya, analisis ilmiah tentang keamanan energi di Indonesia sudah dipublikasikan pertama kali pada tahun 2006 (Indonesia Institute for Energy Economics (IIEE), 2006).

Untuk mendapatkan prediksi yang akurat, maka model keamanan energi Indonesia perlu dikembangkan dengan baik. Ini merupakan suatu tantangan nyata dan juga kesempatan. Secara umum, model yang ada saat ini hanyalah hasil perhitungan, cenderung sebagai analisis prediktif dengan tanpa memberikan gambaran umum dan solusi terperinci tentang apa yang harus dilakukan. Dari hasil pencarian publikasi ilmiah yang membahas tentang Indonesia, baik regional maupun nasional, tidak ada satupun yang secara khusus memberikan analisis lebih rinci mengenai ET dan EE.

Dengan sistem otonomi daerah, maka peran pemerintah daerah sangatlah penting. 
Tujuan dari penelitian ini adalah untuk membahas bagaimana memperbaiki konsep model keamanan energi Indonesia dengan teknik yang merinci indikator energi bersih, dengan fokus pada peran pemerintah daerah yang mendukung pengembangan ET dan EE. Untuk mencapai tujuan tersebut, ada empat tahap konsep penting yang harus diselesaikan, sebagai berikut.

Pertama, menjelaskan konsep perincian indikator ES. Intinya, bagaimana mengubah fokus dan orientasi dari energi fosil kepada pengembangan ET dan EE pada sektor tertentu (sektor residensial, komersial, industri dan transportasi), dan daerah tertentu (pedesaan / perkotaan, Jawa / non-Jawa seperti Sumatera, Kalimantan, Sulawesi, Maluku, Papua, d11.). Sebagai negara berkembang dan kepulauan, yang terbagi atas beberapa propinsi, dengan banyaknya daerah pedesaan di perbatasan yang belum memiliki akses energi yang baik, maka pengembangan keamanan energi Indonesia perlu dimodelkan secara berbeda (Urban, dkk., 2007).

Kedua, menjelaskan hubungan ES dengan detail indicator. Dalam hal ini mengacu kepada Referensi yang dibuat oleh Sovacool and Mukherjee (2011), indikator ET secara inklusif terdapat dalam dimensi utama, yaitu; ketersediaan ( Av, availability), sedangkan EE dalam dimensi pengembangan dan efisiensi teknologi (Ef.efficiency), melengkapi keterjangkauan (Af, affordability), kesinambungan ( $S u$, sustainability), dan tata kelola ( Go, governance).

Ketiga, menjelaskan hubungan antara potensi ET / EE di daerah dengan ES: Dalam pengembangan potensi ET dan ES, agar memberikan dampak dan hasil yang jelas dalam keterbatasan alokasi waktu dan sumber daya yang dimiliki. Dalam hal ini, prinsip fokus dan prioritas bisa diaplikasikan, misalnya dalam jenis ET yang mana dan dimana, begitu juga dengan ES untuk sektor yang mana dan dimana. Prinsip dan fokus tersebut juga dilakukan untuk menjelaskan hubungan EE dan ES.

Keempat, menjelaskan peranan pemerintah daerah dalam ES: Perlu memberikan gambaran, bagaimana seharusnya pemerintah daerah bersikap dan bertindak sesuai dengan payung hukum yang sudah disediakan oleh pemerintah pusat, dalam menunjang ES secara nasional dari konsep ES secara lokal.

\section{PEMBAHASAN}

\section{Konsep Perincian Indikator ET dan EE}

Menurut konsep asli penelitian ini, umumnya untuk ET dan EE, keduanya dibuat secara lebih rinci dengan notasi berdasarkan; Sektor (perumahan $=\mathrm{R}$, komersial $=\mathrm{C}$, transportasi $=\mathrm{T}$, industri $=\mathrm{I}$ ), dan daerah $($ Jawa $=\mathrm{J}$, dari luar Jawa $=$ OJ, meliputi pulau Sumatera (OJS), Kalimantan (OJK), Sulawesi (OJC), Maluku (OJM), Papua (OJP), dll). Kemudian, khusus untuk ET, dapat dibagi menjadi: Surya (S) dan non-Surya (NS), yang dapat dipisahkan untuk Thermal (T) dan Listrik /Electricity (E).

Sebagai contoh, indikator yang menggambarkan ET di sektor industri memiliki notasi IET, atau lebih detail untuk panas matahari (thermal) di Pulau Sumatera (luar Jawa) memiliki notasi OJSTIET. Adapun untuk EE dapat dibagi menjadi: Process $=P$, Utility $=U$, Office $=O$. Dengan demikian dapat dicontohkan, upaya EE dalam proses pendinginan (cooling, C) di industri yang berada di Pulau Jawa memiliki notasi; JCPIEE. Tabel 1 menunjukkan konsep umum untuk merinci ET dan EE 
Tabel 1

Konsep Umum Merinci Untuk Semua Sektor

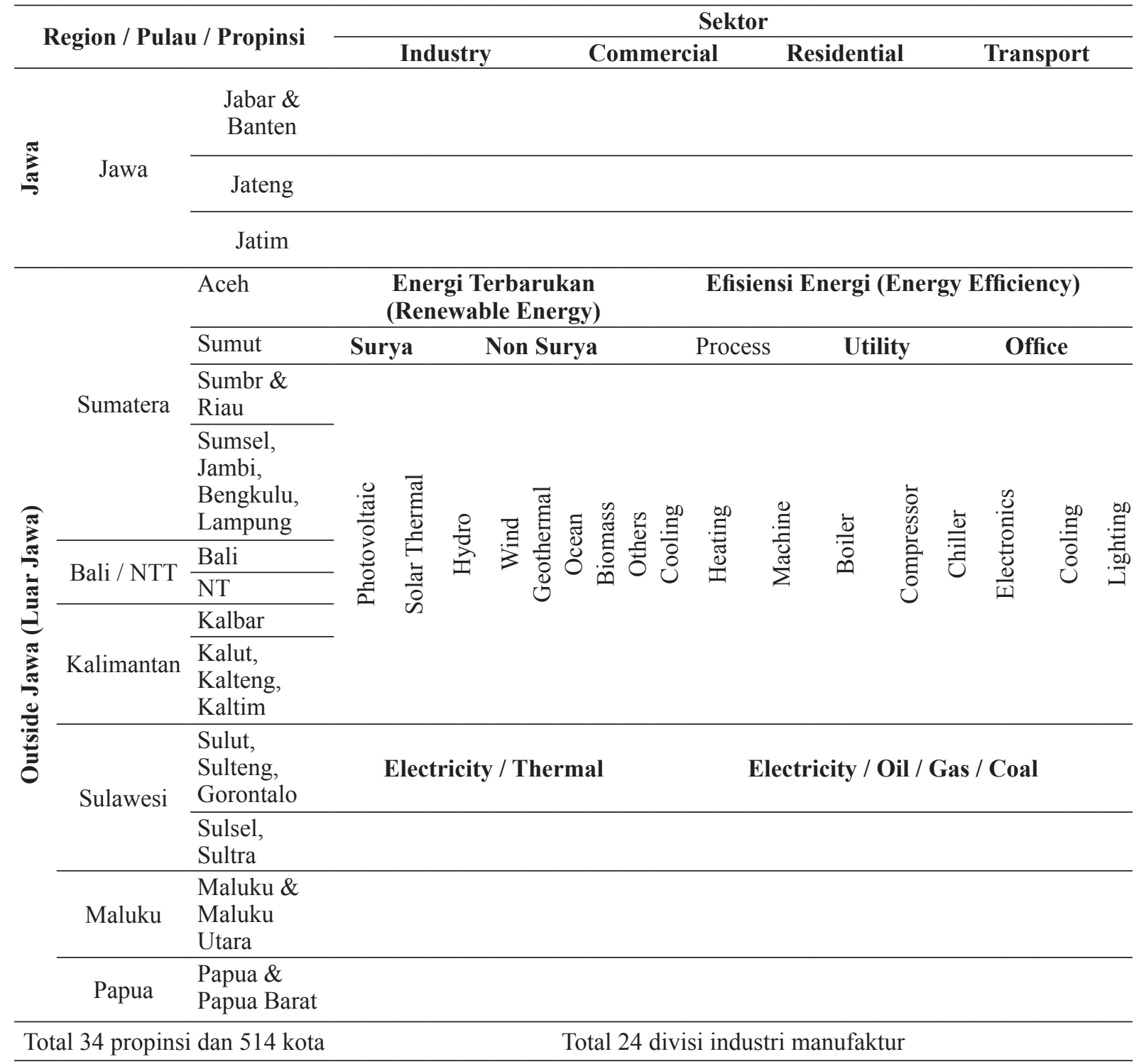

Sumber: Badan Pusat Statistik (BPS), 2014; United Nation (UN), 2008.

untuk semua sektor; industri, komersial, perumahan, dan transportasi.

Selain mendukung keamanan energi nasional, pengembangan ET oleh pemerintah daerah dapat meningkatkan rasio elektrifikasi, mengatasi krisis listrik yang banyak terjadi di daerah, pembangunan kawasan dengan pendekatan pusat ekonomi, sehingga dapat meningkatkan pendapatan daerah (Mary and Armawi, 2017). Didorong oleh berbagai kebutuhan seperti untuk memenuhi kebutuhan mereka sendiri, kesadaran akan isu lingkungan dan menciptakan lapangan kerja, banyak pihak telah memulai pengembangan ET untuk memenuhi kebutuhan tersebut (Martono, 2016). Namun, cakupan pembangunan yang lebih luas yang dihambat oleh beberapa 
Erkata Yandri, Ratna Ariati, Riki Firmandha Ibrahim -- Meningkatkan Keamanan Energi Melalui Perincian Indikator Energi Terbarukan dan Efisiensi Guna Membangun Ketahanan Nasional Dari Daerah

Tabel 2

Konsep Umum Merinci Dari Sektor Ke Energi Terbarukan (renewable energy)

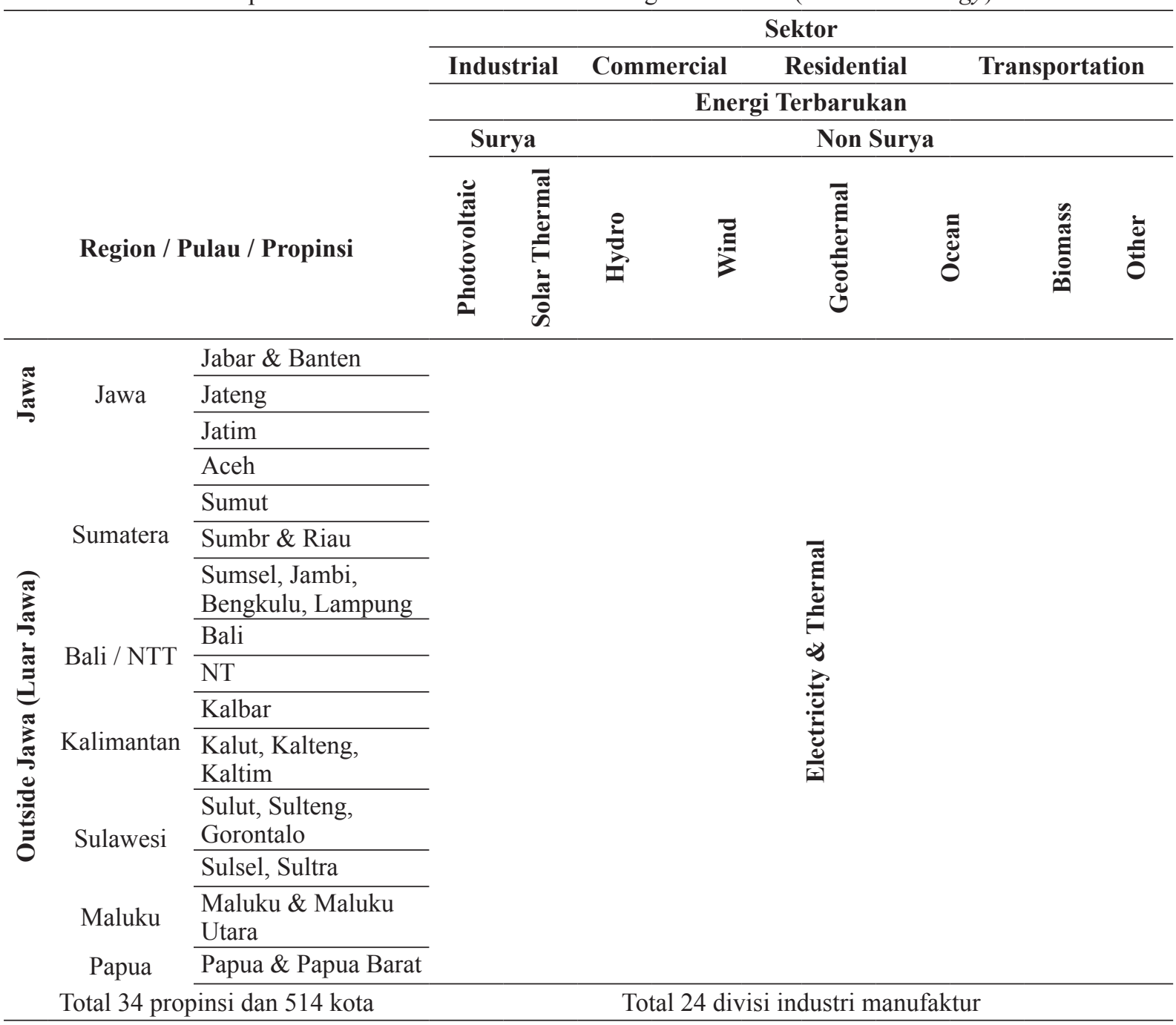

Sumber: Badan Pusat Statistik (BPS), 2014; United Nation (UN), 2008.

kendala, sepertinya kurang mendapat dukungan pemerintah (Buaran, dkk., 2016).

Konsep perincian indikator yang lebih jelas lagi dapat dilihat pada tabel 2 dan tabel 3.

\section{Hubungan Perincian ET Dan ES Terhadap ES}

Keamanan energi ( $E S=$ energy security $)$, untuk semua provinsi dan sektor, dapat dinyatakan secara sederhana dengan:

$$
E S=f(A v+E f+A f+S u+G o)
$$

dimana, $A v, E f, A f, S u$, and $G o$ adalahindikator dari availability (ketersediaan), efficiency (efisiensi), affordability (keterjangkauan), sustainalility (kesinambungan), dan governance (tata kelola). Indikator $A v$ adalah fungsi dari energi fossil (fossil energy, $F E$ ) dan energi terbarukan (renewable energy), yang dinyatakan dengan:

$A v=f(F E+E T)$

Peran FE saat ini yang 92,3\% (Mulyana, 2017) seharusnya dikurangi dengan memperbanyak 
Tabel 3

Konsep Umum Merinci Dari Sektor Keefisiensi Energi (energy efficiency)

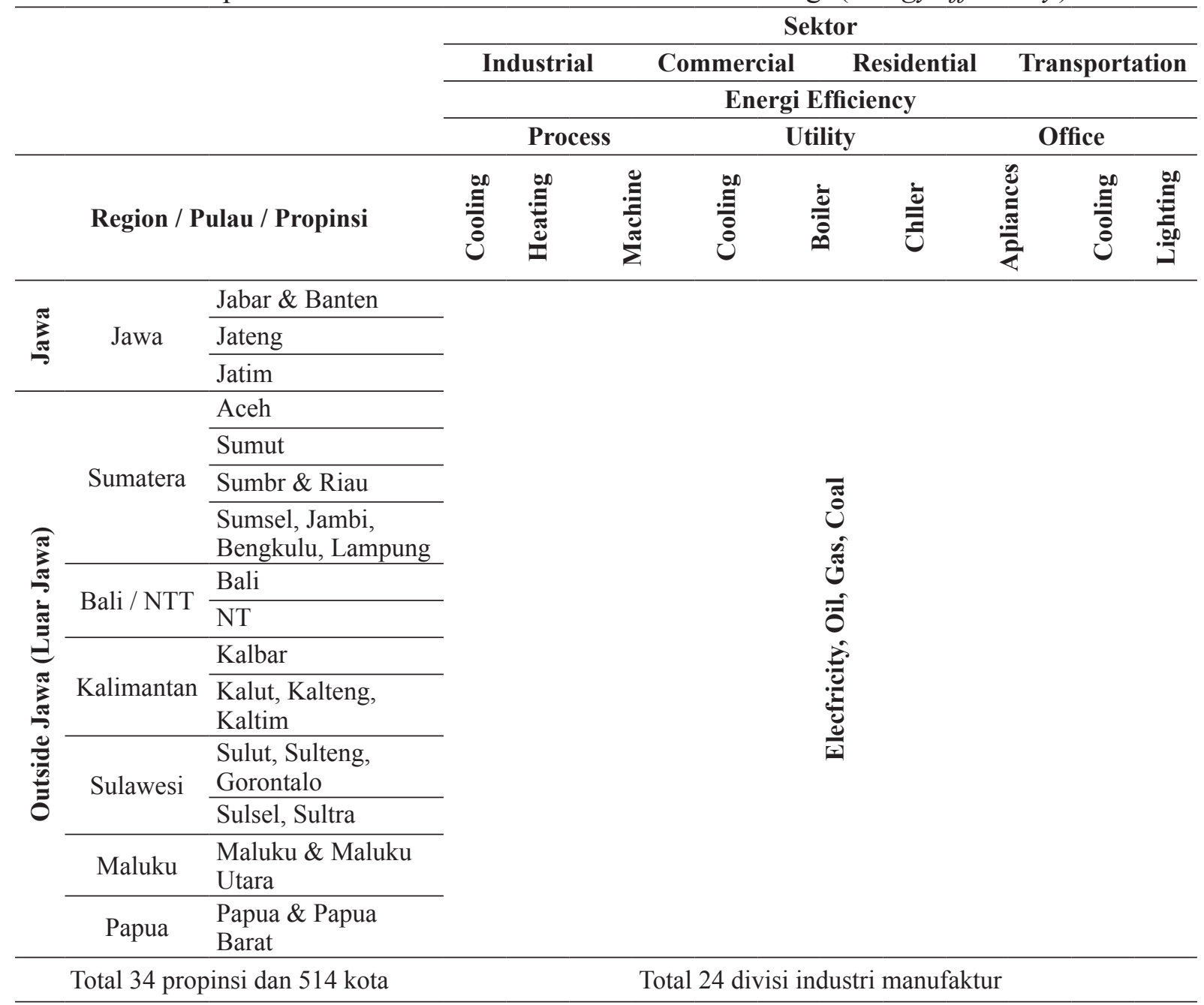

Sumber: Badan Pusat Statistik (BPS), 2014; United Nation (UN), 2008.

hasil dari ETdan EE. Sebagai pengguna energi, yang bertanggung jawab untuk ketersediaan dari energi terbarukan, maka ET dapat dinyatakan dengan:

$$
E T=f(S+N S))
$$

dimana, $S$ and $N S$ adalah Surya and NonSurya. Pada tahap ini, $S$ dan $N S$ hanya untuk menyederhanakannya, tanpa mengabaikan peran dari sumber energi terbarukan lainnya, yang tentunya masih dapat dikembangkan secara lebih rinci pada tahap penelitian selanjutnya.
Sedangkan $E f$ dapat dinyatakan dengan:

$E f=f(E E)$

dimana, $E E$ adalah efisiensi energi, yang dapat dinyatakan untuk di setiap sektor juga dengan:

$$
E E=f(\mathrm{P}+U+O)
$$

Dalam hal ini, $P, U, O$ adalah; process, utility, and office, sebagaimana yang sudah dijelaskan sebelumnya. Mengembangkan efisiensi energi di daerah ini akan memberi 
Erkata Yandri, Ratna Ariati, Riki Firmandha Ibrahim -- Meningkatkan Keamanan Energi Melalui Perincian Indikator Energi Terbarukan dan Efisiensi Guna Membangun Ketahanan Nasional Dari Daerah

Tabel 4

Total Potensi Energi Terbarukan Menurut Wilayah / Provinsi

\begin{tabular}{|c|c|c|c|c|}
\hline \multirow{2}{*}{\multicolumn{3}{|c|}{ Region / Propinsi }} & \multicolumn{2}{|c|}{ Total Potensi } \\
\hline & & & MW & $\%$ \\
\hline \multirow{3}{*}{$\overbrace{\tilde{\Sigma}}^{\pi}$} & \multirow{3}{*}{ Jawa } & Jabar \& Banten & \multirow{3}{*}{$42.995,8$} & \multirow{3}{*}{$24,7 \%$} \\
\hline & & Jateng & & \\
\hline & & Jatim & & \\
\hline \multirow{12}{*}{ 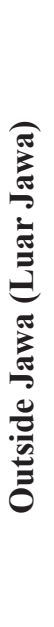 } & \multirow{4}{*}{ Sumatera } & Aceh & \multirow{4}{*}{$5.062,0$} & \multirow{4}{*}{$1.538,0$} \\
\hline & & Sumut & & \\
\hline & & Sumbar\& Riau & & \\
\hline & & $\begin{array}{l}\text { Sumsel, Jambi, Bengkulu, } \\
\text { Lamp. }\end{array}$ & & \\
\hline & \multirow{2}{*}{ Bali / Nusa Teng. } & Bali & \multirow{2}{*}{$15.663,8$} & \multirow{2}{*}{$9,0 \%$} \\
\hline & & Nusa Tenggara & & \\
\hline & \multirow{2}{*}{ Kalimantan } & Kalbar & \multirow{2}{*}{$23.670,2$} & \multirow{2}{*}{$13,6 \%$} \\
\hline & & Kalut, Kalteng, Kaltim & & \\
\hline & \multirow{2}{*}{ Sulawesi } & Sulut, Sulteng, Gorontalo & \multirow{2}{*}{$22.754,6$} & \multirow{2}{*}{$13,1 \%$} \\
\hline & & Sulut, Sultra & & \\
\hline & Maluku & Maluku \&Malut & $5.118,6$ & $2,9 \%$ \\
\hline & Papua & Papua \& Papua Barat & $24.294,6$ & $14,0 \%$ \\
\hline & \multirow{2}{*}{\multicolumn{2}{|c|}{ Total }} & $173.731,4$ & $100 \%$ \\
\hline & & & $100 \%$ & \\
\hline
\end{tabular}

Sumber: Hutapea, 2017.

penghematan dalam konsumsi energi, dalam hal ini tentu akan mengurangi $F E$.

\section{Hubungan Pengembangan Potensi ET Dan EE Di Daerah Terhadap ES}

Seperti ditunjukkan pada tabel 4, masingmasing daerah memiliki potensi energi terbarukan yang tidak sama, terutama untuk panas bumi, pembangkit listrik tenaga air besar maupun kecil, dan angin. Dari ketiga tipe ET tersebut, potensi ET dari yang terbesar ke yang terkecil terdapat di; Jawa (24,7\%), Sumatera (22,6\%), Papua (14,0\%), Kalimantan (13,6\%), Sulawesi (13,1\%), Bali (9\%), dan Maluku (2,9\%). Potensi tenaga air melebihi $50 \%$ dimana sekitar $23 \%$ di Papua, diikuti oleh potensi angin $(33,8 \%)$, dan panas bumi $(15,7 \%)$.

Dari pemetaan potensi energi terbarukan, dengan memperhitungkan bahwa (1). Lebih dari $60 \%$ penduduk
Indonesia berada di Pulau Jawa (Badan Pusat Statistik (BPS), 2014), (2). Hampir $80 \%$ kapasitas listrik terpasang terdapat di Jawa-Bali (Perusahaan Listrik Negara (PLN), 2013), dan (3). Sumber energi fosil seperti batubara yang berasal dari luar Jawa, maka pengembangan energi berbasis energi terbarukan harus lebih dipercepat dan didorong di Jawa.

Perhitungan ini tanpa bermaksud mengenyampingkan pentingnya daerah di luar Jawa. Artinya, setiap pemerintah daerah harus berkompetisi dalam mengembangkan potensi energi terbarukan di daerahnya masing-masing.

Berdasarkan penyajian Direktur Konservasi Energi, pada tanggal 15 September 2017, di IndoEBTKE ConEx 2017 (Dirjen EBTKE/KESDM, 2017) sebagai terlihat pada tabel 5, ada 244 perusahaan yang diidentifikasi 
wajib menerapkan manajemen energi dan melaporkan konsumsi energinya sebagaimana diatur oleh Pemerintah (Peraturan Pemerintah RI, 2009). Perusahaan-perusahaan tersebut yang mengkonsumsi sekitar 6.000 TOE (ton of oil equivalent, setara ton minyak), kebanyakan berasal dari beberapa jenis industri, dengan hanya 1 perusahaan saja yang bergerak di bidang konstruksi.

Sebagaimana yang terlihat pada tabel 6 , pemerintah juga menggambarkan distribusi 11 provinsi yang merupakan pengguna energi terbesar, dengan konsumsi sekitar 91\% dari konsumsi energi nasional (Dirjen EBTKE/ KESDM, 2017). Mereka menjadi target kampanye pemerintah untuk mengurangi penggunaan energi sebesar $10 \%$. Perlu dicatat, bahwa efisiensi energi yang tinggi terkait dengan faktor produktivitas total yang tinggi pula di sektor manufaktur, seperti; tekstil, pakaian, makanan, kayu dan furnitur, agroindustri, dan bahan kimia (Cantore,dkk., 2016).

Penjelasan lebih rinci tentang potensi mikro hydro, panas bumi, dan energi angina di berbagai wilayah atau provinsi di Indonesia dapat dilihat pada tabel 7, tabel 8, dan tabel 9.

Melalui program Konservasi Energi, Kementerian ESDM menerapkan beberapa program tambahan dengan merangkai Standar dan membubuhi Label (S/L) Solusi Energi dan label Standar Kinerja Energi Minimum (MEPS) untuk peralatanlampu CFL, AC, Kulkas, Kipas Angin, Penanak Nasi, Motor Listrik dan Ballast Elektronik, serta menyusun kode bangunan (ESDM, 2016).

Agar memiliki skala besar dan dampak yang langgeng, kebijakan EE harus melibatkan semua sektor, dengan lebih fokus pada sektor swasta (Geller, dkk,. 2006). Contohnya, beralih dari industri padat energi

Tabel 5

Identified Companies For Energy Management

\begin{tabular}{clr}
\hline No. & \multicolumn{1}{c}{ Manufacture Industry Division } & Companies \\
\hline 1 & Textile industry & 40 \\
2 & Iron \& steel industry & 34 \\
3 & Manufacturing industry & 30 \\
4 & Pulp \& paper industry & 20 \\
5 & Power plant industry & 20 \\
6 & Agro industry & 13 \\
7 & Chemical industry & 11 \\
8 & Petrochemical industry & 11 \\
9 & Food industry & 11 \\
10 & Beverage industry & 4 \\
11 & Fertilizer industry & 8 \\
12 & Cement industry & 8 \\
13 & Motor vehicle industry & 8 \\
14 & Coal \& minerals mining industry & 8 \\
15 & Oil \& gas industry & 10 \\
16 & Other industries (cigarettes, etc.) & 7 \\
17 & Construction building industry & 1 \\
\hline & & Total perusahaan
\end{tabular}

Sumber: Finahari, 2017. 
Erkata Yandri, Ratna Ariati, Riki Firmandha Ibrahim -- Meningkatkan Keamanan Energi Melalui Perincian Indikator Energi Terbarukan dan Efisiensi Guna Membangun Ketahanan Nasional Dari Daerah

Tabel 6

Propinsi Yang Ditargetkan Untuk 10\% Energy Consumption Cutting

\begin{tabular}{clrr}
\hline \multirow{2}{*}{ No. } & & \multicolumn{1}{c}{ Propinsi } & \multicolumn{2}{c}{$\begin{array}{c}\text { Konsumsi dalam } \\
\text { 2014 }\end{array}$} \\
\hline 1 & Banten & 51.277 & 51.257 \\
2 & Jawa Barat & 41.269 & 41.328 \\
3 & DKI Jakarta \& Tangerang & 30.523 & 30.824 \\
4 & Jawa Timur & 19.631 & 22.892 \\
5 & Jawa Tengah & 8.271 & 8.703 \\
6 & Sumatera Utara & 6.199 & 6.606 \\
7 & Sumatera Selatan & 5.247 & 5.441 \\
8 & Sulawesi Selatan & 4.335 & 4.594 \\
9 & Bali & 3.971 & 4.241 \\
10 & Riau & 3.392 & 3.570 \\
11 & Lampung & $\mathbf{1 7 4 . 1 1 5}$ & $\mathbf{1 7 9 . 4 5 6}$ \\
\hline & $\quad$ Total & &
\end{tabular}

Sumber: Finahari, 2017.

Tabel 7

Potensi Mikro Hydro Menurut Wilayah / Provinsi

\begin{tabular}{|c|c|c|c|c|}
\hline \multirow{2}{*}{\multicolumn{3}{|c|}{ Region / Propinsi }} & \multicolumn{2}{|c|}{ (MW) } \\
\hline & & & \multirow{2}{*}{$\frac{\text { Besar }}{2.861,0}$} & \multirow{2}{*}{$\frac{\text { Mini/Mikro }}{0,7}$} \\
\hline \multirow{12}{*}{ 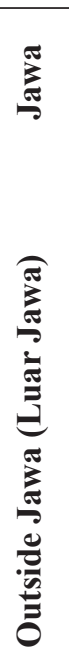 } & \multirow{3}{*}{ Jawa } & Jabar \& Banten & & \\
\hline & & Jateng & 0,8 & $1.049,0$ \\
\hline & & Jatim & 0,5 & $1.142,0$ \\
\hline & \multirow{4}{*}{ Sumatera } & Aceh & $5.062,0$ & $1.538,0$ \\
\hline & & Sumut & $3.808,0$ & $1.204,0$ \\
\hline & & Sumbar\& Riau & $3.607,0$ & $1.637,0$ \\
\hline & & Sumsel, Jambi, Bengkulu, Lamp. & $3.102,0$ & $1.355,0$ \\
\hline & Bali / Nusa Teng. & $\begin{array}{c}\text { Bali } \\
\text { Nusa Tenggara }\end{array}$ & 0,6 & 0,1 \\
\hline & \multirow{2}{*}{ Kalimantan } & Kalbar & $4.737,0$ & 0,1 \\
\hline & & Kalut, Kalteng, Kaltim & $16.844,0$ & 8,0 \\
\hline & \multirow{2}{*}{ Sulawesi } & Sulut, Sulteng, Gorontalo & $3.967,0$ & 0,6 \\
\hline & & Sulut, Sultra & $6.340,0$ & $1.070,0$ \\
\hline & Maluku & Maluku \&Malut & 0,4 & 0,2 \\
\hline & Papua & Papua \& Papua Barat & $22.371,0$ & 0,6 \\
\hline & \multirow{2}{*}{\multicolumn{2}{|c|}{ Total }} & $98.634,1$ & $0.005,4$ \\
\hline & & & $45,5 \%$ & $5,2 \%$ \\
\hline
\end{tabular}

Sumber: Hutapea, 2017.

(pertambangan, logam dasar, bahan kimia, petrokimia, dll) ke manufaktur, layanan intensif, dan sebagainya. Langkah selanjutnya adalah proses pembandingan EE, terutama ke provinsi lain atau negara maju. seperti Jepang, Jerman, dll (Honma dan $\mathrm{Hu}, 2014)$.

Konsumsi energi terbarukan memiliki dampak positif yang signifikan terhadap 
Tabel 8

Potensi Panas Bumi Menurut Wilayah / Provinsi

\begin{tabular}{|c|c|c|c|}
\hline \multicolumn{3}{|c|}{ Region / Propinsi } & \multirow[t]{2}{*}{ MWe } \\
\hline \multirow{4}{*}{$\stackrel{\pi}{=}$} & & Jabar \& Banten & \\
\hline & Jawa & Jateng & $9.017,0$ \\
\hline & & Jatim & \\
\hline & & Aceh & \\
\hline \multirow{10}{*}{ 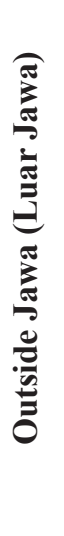 } & & Sumut & \\
\hline & Sumatera & Sumbar\& Riau & $11.772,0$ \\
\hline & & nsel, Jambi, Bengkulu, Lamp. & \\
\hline & Deli / Tuco Tano & Bali & 354,0 \\
\hline & Balı / Nusa Teng. & Nusa Tenggara & $1.497,0$ \\
\hline & Kalimantan & $\begin{array}{c}\text { Kalbar } \\
\text { Kalut Kalteno Kaltim }\end{array}$ & 182,0 \\
\hline & & Sulut, Sulteng, Gorontalo & \\
\hline & Sulawesi & Sulut, Sultra & $2.997,0$ \\
\hline & Maluku & Maluku \&Malut & $1.426,0$ \\
\hline & Papua & Papua \& Papua Barat & 75,0 \\
\hline \multirow{2}{*}{\multicolumn{3}{|c|}{ Total }} & $27.320,0$ \\
\hline & & & $15,7 \%$ \\
\hline
\end{tabular}

Sumber: Hutapea, 2017.

Tabel 9

Potensi Energi Angin Menurut Wilayah / Provinsi

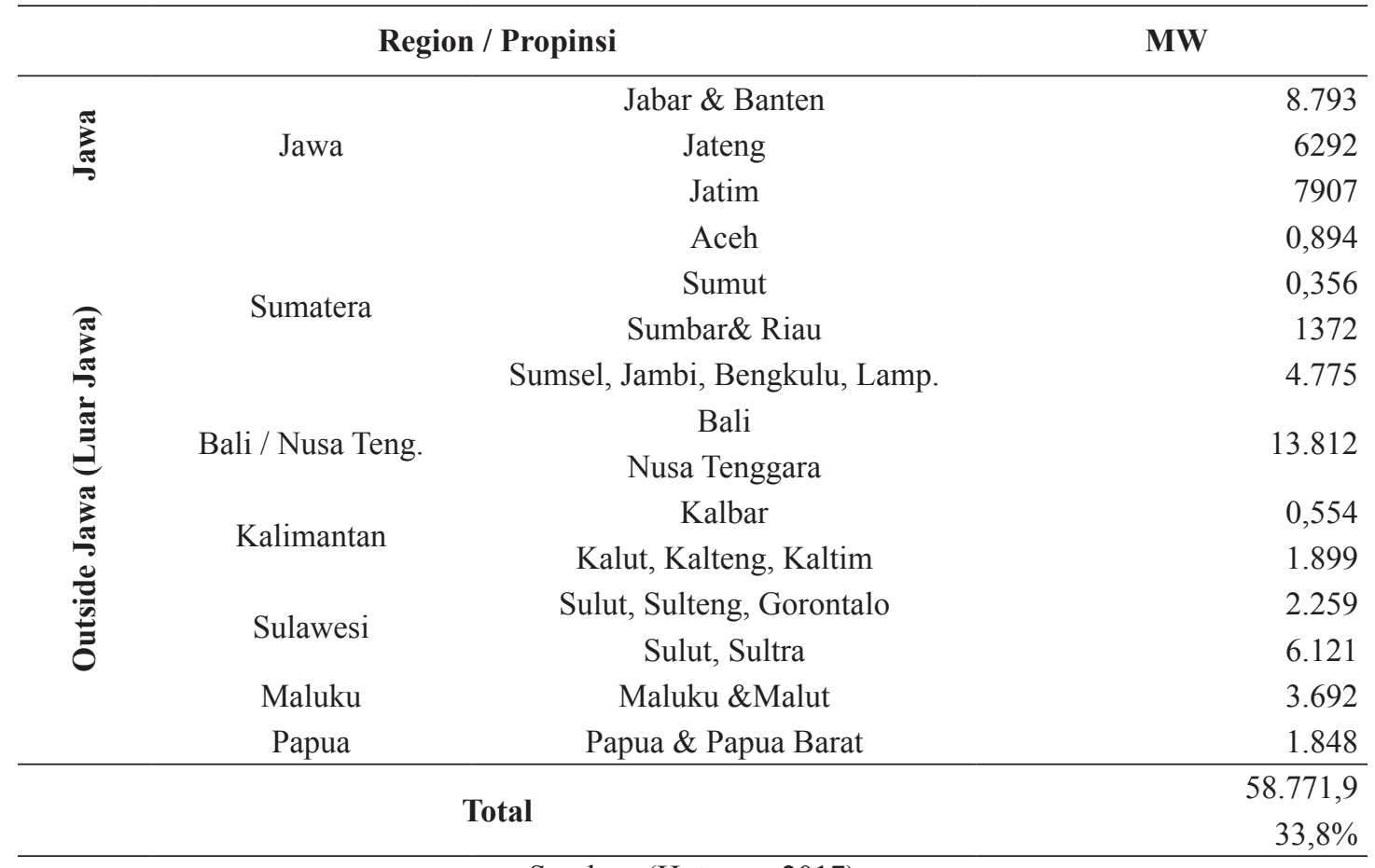

Sumber: (Hutapea, 2017) 
pertumbuhan ekonomi dalam jangka panjang, yang mencerminkan penerapan terkait dengan penciptaan lapangan kerja jangka panjang (Bhattacharya, dkk., 2016), dan juga arus masuk positif investasi asing langsung (FDI, foreign direct investment) (Reddy, dkk., 2016). Penciptaan lapangan kerja dan masuknya investasi juga terjadi di upaya peningatan EE.

Sebagai referensi, dari program efisiensi energi di negara bagian California, diprediksi lebih dari 400 ribu pekerjaan langsung dan tidak langsung dapat diciptakan pada tahun 2020 (Roland-Holst, 2008). Dalam hal pengembangan efisiensi energi, sebaiknya juga dipercepat dan didorong di Jawa karena energi nasional banyak dikonsumsi di Pulau Jawa (Yandri, dkk., 2017). Akhirnya, dengan memprioritaskan pengembangan energi terbarukan dan efisiensi energi diharapkan kemandirian dan keamanan energi lokal maupun nasional akan tercapai.

\section{Peranan Pemerintah Daerah untuk ET dan EE}

Upaya pemanfaatan energi terbarukan dan efisiensi energi telah diamanatkan dalam Undang-Undang (UU Energi No. 30 Tahun 2007). Selanjutnya, pemerintah daerah sebaiknya menyesuaikan kebijakannya pemerintah yang disesuaikan dengan profil regionalnya. Pemerintah daerah memiliki tanggung jawab untuk mengembangkan program energi yang dapat ditindaklanjuti ke dalam pelaksanaannya (Rijanto, 2011). Namun, sebagai akibat dari sistem pemerintahan otonom, banyak pemerintah daerah belum mengambil langkah maju untuk mendukung kebijakan nasional dan bekerja secara independen. Dapat dikatakan bahwa langkah untuk menunjang konsep ketahanan energi nasional dengan mengembangkan energi alternatif ini masih belum ada.

Konsep model keamanan energi melalui perincian indikator energi terbarukan dan energi efisiensi menawarkan atas masalah yang dihadapi oleh Pemerintah Daerah dalam menerapkan pengembangan energi terbarukan, sebagaimana diamanatkan oleh UndangUndang No. 30 tahun 2007 tentang Energi dan semua peraturan derivatifnya. Indikator detail secara otomatis memberikan indikator kinerja energi utama (KEPI, key energy performance indicator) dengan memanfaatkan indikator notasi yang lebih rinci untuk ET dan EE, serta indikator penyusun lainnya.

Pengertian KPI secara umum antara lain; ukuran perilaku sistem dalam hal atribut yang bermakna dan jelas; ukuran yang merangkum informasi yang relevan dengan fenomena tertentu, atau ke perwakilan yang wajar untuk mengukur; parameter, atau nilai yang berasal dari parameter, yang menunjuk / menyediakan informasi tentang / menjelaskan fenomena / lingkungan / area dengan signifikansi yang melampaui batas yang secara langsung terkait dengan parameter (properti yang diukur atau diamati) nilai; dan; variabel yang menggambarkan sistem, di mana variabel adalah representasi operasional dari suatu atribut (kualitas, karakteristik, properti) dari sistem dan ini mewakili citra kita tentang atribut yang didefinisikan dalam hal pengukuran spesifik atau prosedur observasi (Perotto, dkk., 2008).

Di sini, peranan perencanaan strategis untuk energi sangatlah penting. Untuk memulai dengan mempertimbangkan bagaimana informasi tersebut sistem akan mendukung tujuan utama dalam rencana manajemen energi. Jika tujuan ini adalah ekspresi terbaik dari apa yang diharapkan organisasi untuk 
Gambar 6

Contoh Konsep Sistem Dashboard Untuk Kemudahan Pemantauan Dan Tindak Lanjut

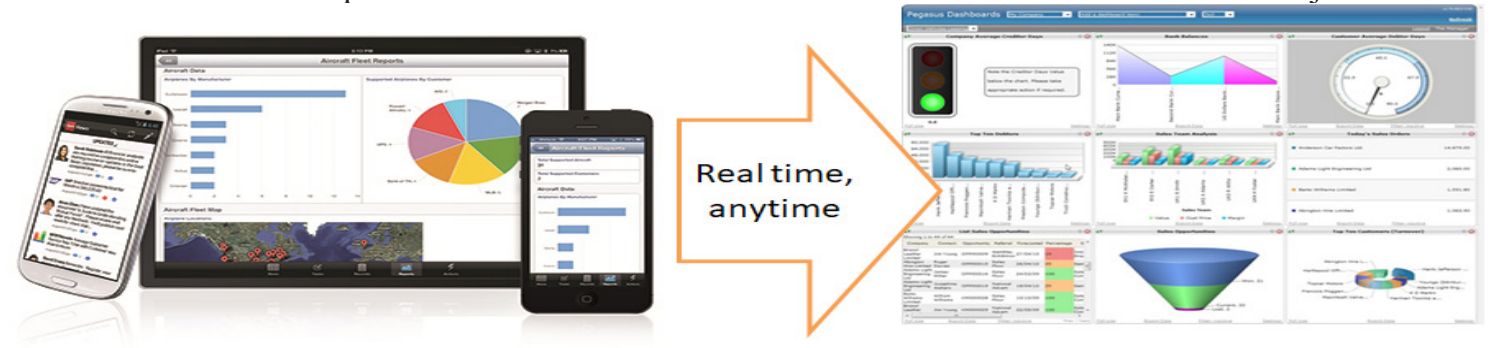

Sumber: Yandri, dkk., 2017.

dicapai dalam mengelola energinya, maka langkah pertama adalah mengubah sasaran tersebut menjadi indikator kinerja utama (KPI) yang dapat diukur dan dilacak.

Dalam hal ini, kita akan mengetahui secara lebih rinci kontribusi ET atau EE di masing-masing sektor, atau di suatu wilayah atau pulau terhadap indikator dari PDB. Jadi bisa lebih jelas melihat peta jalan ET dan EE, serta isu dan tindakan yang akan diambil.

Model keamanan energi yang terperinci ini dapat disederhanakan ke dalam indeks komposit, yang bisa ditampilkan di dashboard agar mudah dipahami, dilacak dan ditindaklanjuti. Dengan berkembangnya teknologi komunikasi saat ini, tentu akan semakin mudah diakses dari komputer dan telepon genggam oleh pemangku kepentingan, seperti yang ditunjukkan pada gambar 6 .

Secara umum, konsep ini dapat menganalisis keamanan energi dengan kondisi energi yang kompleks secara lokal/nasional, dengan memusatkan perhatian pada kontribusi ET dan EE untuk semua sektor. Untuk itu, pemerintah daerah perlu melakukan beberapa hal berikut.

Pertama, memanfaatkan indikator notasi rinci ET dan EE sebagai indikator kinerja energi utama (KEPI), untuk mengidentifikasi masalah yang lebih jelas terkait dengan keamanan energi, di mana dan tindakan apa yang akan diambil segera. Indikator notasi rinci harus dilakukan dengan benar.

Kedua, melacak kinerja keamanan energi tentang bagaimana memantau, mengendalikan, dan mengelola masalah energi. Ini bisa memberi gambaran kemajuan keamanan energi lokal/nasional dari waktu ke waktu, selama implementasi dapat melakukan tindakan korektif, inovasi, dan akselerasi.

Ketiga, mengembangkan kebijakan ET dan EE yang komprehensif untuk perencanaan jangka panjang keamanan energi lokal/ nasional, karena aktifitas kebijakan energi telah didefinisikan secara jelas dalam model menjadi indikator untuk dinilai dengan mudah dan cepat. Pemerintah daerah diharapkan lebih selektif dan berhati-hati dalam mengeluarkan kebijakan sektoral (perumahan, industri, komersial, dan transportasi).

Keempat, menguji dan membuktikan beberapa gagasan atau saran sebelum kebijakan diambil dengan menggunakan simulasi model keamanan energi. Meningkatkan keamanan energi nasional ke depan, Indonesia harus mempertimbangkan untuk memperketat subsidi energi daripada hanya untuk meningkatkan produksi energy (Prambudia and Nakano, 2012).

Berdasarkan apa yang telah dibahas, untuk menjamin keamanan energi, Indonesia harus lebih serius dan fokus pada pengembangan energi terbarukan dan 
efisiensi energi. Konsep merinci ET dan EE, untuk memperbaiki model keamanan energi saat ini, sejalan dengan upaya untuk memperkuat keamanan energi. Peranan pemerintah daerah sangat penting untuk mengejar perkembangan ET dan EE dalam mencapai tujuan tersebut, sebagai kontribusi pemerintah daerah dalam menerapkan UU Energi. Artinya, pemerintah daerah harus mempertimbangkan keamanan energi lokal / regional. Dalam menyusun rencana strategis dan rencana kerja, setiap pemerintah daerah, provinsi maupun kabupaten/kota, harus mengacu kepada RUEN. Dengan kata lain, penyusunan rencana umum energi lokal / regional (RUED) mengacu pada semua yang telah digariskan dalam Peraturan Presiden.

Dengan indikator energi terbarukan dan efisiensi energi yang lebih terperinci, maka dapat membantu pemerintah daerah dalam mengevaluasi kinerja masing-masing sektor dalam mencapai target energi nasional yang telah ditetapkan.Konsep ini bisa dikembangkan lebih lanjut, baik secara teknis pengembangan / perincian indikator ET dan EE yang lebih spesifik untuk suatu daerah, maupun teknis pemodelan yang disesuaikan dengan kemudahan aplikasi kemajuan teknologi informasi saat ini.

Selanjutnya, tugas pemerintah pusat untuk membuat suatu aturan main dalam memberikan apresiasi terhadap pencapaian atau kontribusi ES dari masing-masing pemerintah daerah tersebut, agar timbul suatu dinamika kompetisi yang sehat dari masingmasing pemerintah daerah.

\section{SIMPULAN}

Berdasarkan pemaparan di atas, maka dapat diambil beberapa simpulan sebagai berikut.
Pertama, pengembangan ET dan EE merupakan suatu keniscayaan karena telah diamanatkan oleh Undang-Undang.

Kedua, konsep perincian indikator ES dengan indikator utama; availability (ketersediaan), efficiency (efisiensi), affordability (keterjangkauan), sustainalility (kesinambungan), dan governance, perlu melibatkan potensi di semua sektor, yaitu residensial, komersial, industrial, dan transportasi, yang juga mencakup perincian di semua jenis ET (surya dan non surya) dan EE di semua sektor.

Ketiga, kontribusi ET dan EE terhadap ES dapat dilihat dari hubungan empiris terhadap 5 kategori indikator utama tsb.

Keempat, untuk mendapatkan hasil yang jelas dan terukur, maka pengembangan potensi ET dan EE harus dengan prinsip fokus dan prioritas, agar potensi ET dan EE di daerah bisa terwujud secara optimal dan terukur.

Kelima, dengan perincian indikator ES, maka akan mempermudah pemerintah daerah dalam berkontribusi terhadap ES secara nasional melalui pengembangan ET dan EE di daerahnya masing-masing.

\section{DAFTAR PUSTAKA}

Ang, B.W., Choong, W.L. and Ng, T.S., 2015. Energy security: Definitions, dimensions and indexes. Renewable and Sustainable Energy Reviews, [online] 42, pp.1077-1093. Available at: <http:// linkinghub.elsevier.com/retrieve/pii/ S1364032114008892>.

Badan Pusat Statistik (BPS), 2014. Statistical Yearbook of Indonesia. [online] Jakarta. Available at: <http://www.bps.go.id>.

Bhattacharya, M., Paramati, S.R., Ozturk, I. and Bhattacharya, S., 2016. The effect of renewable energy consumption on 
economic growth : Evidence from top 38 countries. APPLIED ENERGY, [online] 162(November 2015), pp.733-741. Available at: $<$ http://dx.doi.org/10.1016/j. apenergy.2015.10.104>.

Bielecki, J., 2002. Energy security: Is the wolf at the door? Quarterly Review of Economics and Finance, 42(2), pp.235-250.

British Petroleum (BP), 2017. BP Statistical Review of World Energy 2017. [online] Available at: <http://www.bp.com $>$.

Buaran, B., Armawi, A. and Martono, E., 2016. Peran Pembangkit Listrik Tenaga Biogas dalam Mewujudkan Ketahanan Nasional. Jurnal Ketahanan Nasional, 22(3, 27 Desember 2016), pp.241-154.

Cantore, N., Calì, M. and Willem, D., 2016. Does energy ef fi ciency improve technological change and economic growth in developing countries ? Energy Policy, [online] 92, pp.279-285. Available at: $<$ http://dx.doi.org/10.1016/j. enpol.2016.01.040>.

Cherp, A. and Jewell, J., 2011. The three perspectives on energy security: Intellectual history, disciplinary roots and the potential for integration. Current Opinion in Environmental Sustainability, [online] 3(4), pp.202-212. Available at: <http://dx.doi.org/10.1016/j. cosust.2011.07.001>.

Chester, L., 2010. Conceptualising energy security and making explicit its polysemic nature.

Energy Policy, [online] 38(2), pp.887-895. Available at: $<$ http://dx.doi.org/10.1016/j. enpol.2009.10.039>.

Dirjen EBTKE/KESDM, 2017. Kebijakan dan program konservasi energi.
ESDM, K., 2016. Program Strategis EBTKE dan Ketenagalistrikan. [online] Journal Energi, Available at: $<w w w . e s d m . g o . i d>$.

Finahari, I.N., 2017. Program Konservasi Energi. Jakarta.

Geller, H., Harrington, P. and Rosenfeld, A.H., 2006. Polices for increasing energy efficiency: Thirty years of experience in OECD countries. 34, pp.556-573.

Gunningham, N., 2013. Managing the energy trilemma: The case of Indonesia. Energy

Policy, [online] 54, pp.184-193. Available at: <http://dx.doi.org/10.1016/j. enpol.2012.11.018>.

Harris, 2018. Pengelolaan Energi Baru Dan Energi Terbarukan Di Indonesia.

Honma, S. and Hu, J.L., 2014. Industry-level total-factor energy efficiency in developed countries: A Japan-centered analysis. Applied Energy, [online] 119, pp.67-78. Available at: $<$ http://dx.doi.org/10.1016/j. apenergy.2013.12.049>.

Hutapea, M., 2017. Policy, Target, and Breakthrough in Wind to Support National Energy

Policy and Paris Agreement. [online] Available at: <http://www.indoebtkeconex.com/ downloadmaterials/\#1505419087689c65b669d-201d>.

Indonesia Institute for Energy Economics (IIEE), 2006. Surviving Energy Challenges.

Indonesia Energy Economic Review, [online] 1. Available at: <http://iiee.or.id/journalieer/s.

International Energy Agency (IEA), 2018. Energy security. [online] Available at: $<\mathrm{http}$ ://www.iea.org/topics/energysecurity/ 
Erkata Yandri, Ratna Ariati, Riki Firmandha Ibrahim -- Meningkatkan Keamanan Energi Melalui Perincian Indikator Energi Terbarukan dan Efisiensi Guna Membangun Ketahanan Nasional Dari Daerah

subtopics/whatisenergysecurity/> [Accessed 22 Apr. 2018].

Johansson, B., 2013. A broadened typology on energy and security. Energy, [online] 53, pp.199-205. Available at: <http://dx.doi. org/10.1016/j.energy.2013.03.012>.

Kiriyama, E. and Kajikawa, Y., 2014. A multilayered analysis of energy security research and the energy supply process. Applied Energy, [online] 123, pp.415-423. Available at: $<$ http://dx.doi.org/10.1016/j. apenergy.2014.01.026>.

Månsson, A., Johansson, B. and Nilsson, L.J., 2014. Assessing energy security: An overview of commonly used methodologies. Energy, 73, pp.1-14.

Martono, E. and Prasetya, A., 2016. Peran Pemuda dalam Pengembangan Eduwisata Energi Terbarukan dan Implikasinya terhadap Pengembangan Ekonomi Jurnal Ketahanan Nasional, 22(3, 27 Desember 2016), pp.285-305.

Mary, R.T., Armawi, A. and Hadna, A.H., 2017. Panas Bumi Sebagai Harta Karun Untuk Menuju Ketahanan Energi Ketergantungan Indonesia terhadap energi terhadap fluktuasi ketersediaan dan harga. Jurnal Ketahanan Nasional, 23(2, Agustus 2017), pp.93-113.

Mujiyanto, S. and Tiess, G., 2013. Secure energy supply in 2025: Indonesia's need for an energy policy strategy. Energy Policy, [online] 61(5), pp.31-41. Available at: $<$ http://dx.doi.org/10.1016/j. enpol.2013.05.119>.

Mulyana, R., 2017. Pengembangan EBTKE. [online] Jakarta. Available at: <http://www.indoebtkeconex.com/ downloadmaterials/\#149464300070049414ff0-a95f>.
Pappas, D., Chalvatzis, K.J., Guan, D. and Ioannidis, A., 2018. Energy and carbon intensity: A study on the crosscountry industrial shift from China to India and SE Asia. Applied Energy, [online] 225(April), pp.183-194. Available at: $<$ https://doi.org/10.1016/j. apenergy.2018.04.132>.

Perotto, E., Canziani, R., Marchesi, R. and Butelli, P., 2008. Environmental performance, indicators and measurement uncertainty in EMS context: a case study. Journal of Cleaner Production, 16(4), pp.517-530.

Perusahaan Listrik Negara (PLN), 2013. Statistik PLN. [online] Available at: $<$ http://www.pln.co.id $>$.

Pusdatin ESDM, 2014. Handbook of Energy \& Economic Statistics of Indonesia 2014. [online] Available at: <http://www.esdm. go.id>.

Reddy, S., Ummalla, M. and Apergis, N., 2016. The effect of foreign direct investment and stock market growth on clean energy use across a panel of emerging market economies. Energy Economics, [online] 56, pp.29-41. Available at: <http://dx.doi. org/10.1016/j.eneco.2016.02.008>.

Rijanto, M.W. and Armawi, A., 2011. Peran pemda dan masyarakat dalam pengembangan energi alternatif.pdf. Jurnal Ketahanan Nasional, 35-48(XV1 (3)).

Roland-holst, D., 2008. Energy Efficiency, Innovation, and Job Creation in California. [online] Berkeley. Available at: <https:// escholarship.org/content/qt7qz3b977/ qt7qz3b977.pdf>.

Sovacool, B.K. and Mukherjee, I., 2011. Conceptualizing and measuring energy 
security: A synthesized approach. Energy, [online] 36(8), pp.5343-5355. Available at: $<h t t p: / / d x$.doi.org/10.1016/j. energy.2011.06.043>.

United Nation (UN), 2008. International Standard Industrial Classification of All Economic Activities (ISIC), Rev.4.

Urban, F., Benders, R.M.J. and Moll, H.C., 2007. Modelling energy systems for developing countries. Energy Policy, 35(6), pp.3473-3482.

Vivoda, V., 2010. Evaluating energy security in the Asia-Pacific region: A novel methodological approach. Energy Policy, [online] 38(9), pp.5258-5263. Available at: $<$ http://dx.doi.org/10.1016/j. enpol.2010.05.028>.

World Energy Council, 2017. World Energy Trilemma Index. [online] p.145. Available at: <https://www.worldenergy.org/
wp-content/uploads/2017/11/EnergyTrilemma-Index-2017-Report.pdf>.

Yandri, E., Ariati, R. and Ibrahim, R., 2017. Improving Energy Security Model through Detailing Renewable and Energy Efficiency Indicators : A Concept for Manufacture Industry. In: SIGER 2017. [online] Universitas Lampung, p.9. Available at: <http://siger.unila.ac.id/ publications/>.

\section{Peraturan Perundangan}

Undang-Undang RI Nomor 30 Tahun 2007 Tentang Energi

Peraturan Presiden RI Nomor 22 Tahun 2017 Tentang Rencana Umum Energi Nasional Peraturan Pemerintah RI Nomor 70 Tahun 2009 Tentang Konservasi Energi..

Peraturan Pemerintah Nomor 79 Tahun 2014 Tentang Kebijakan Energi Nasional. 